
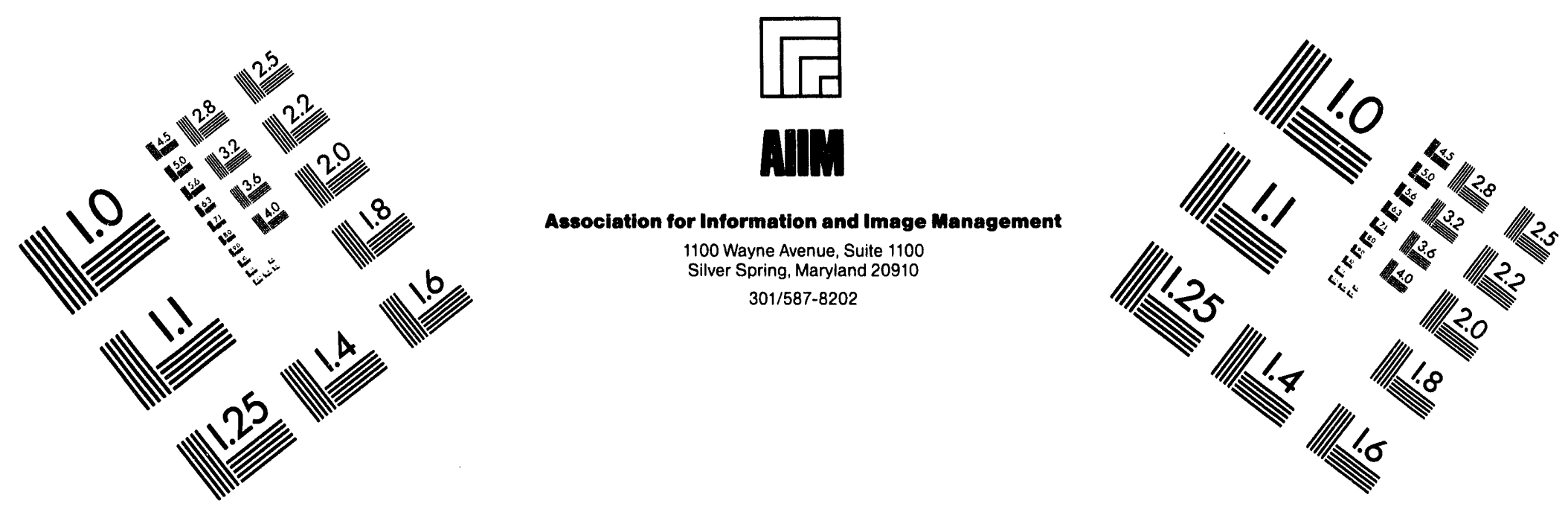

\title{
Centimeter
}

1 Inches
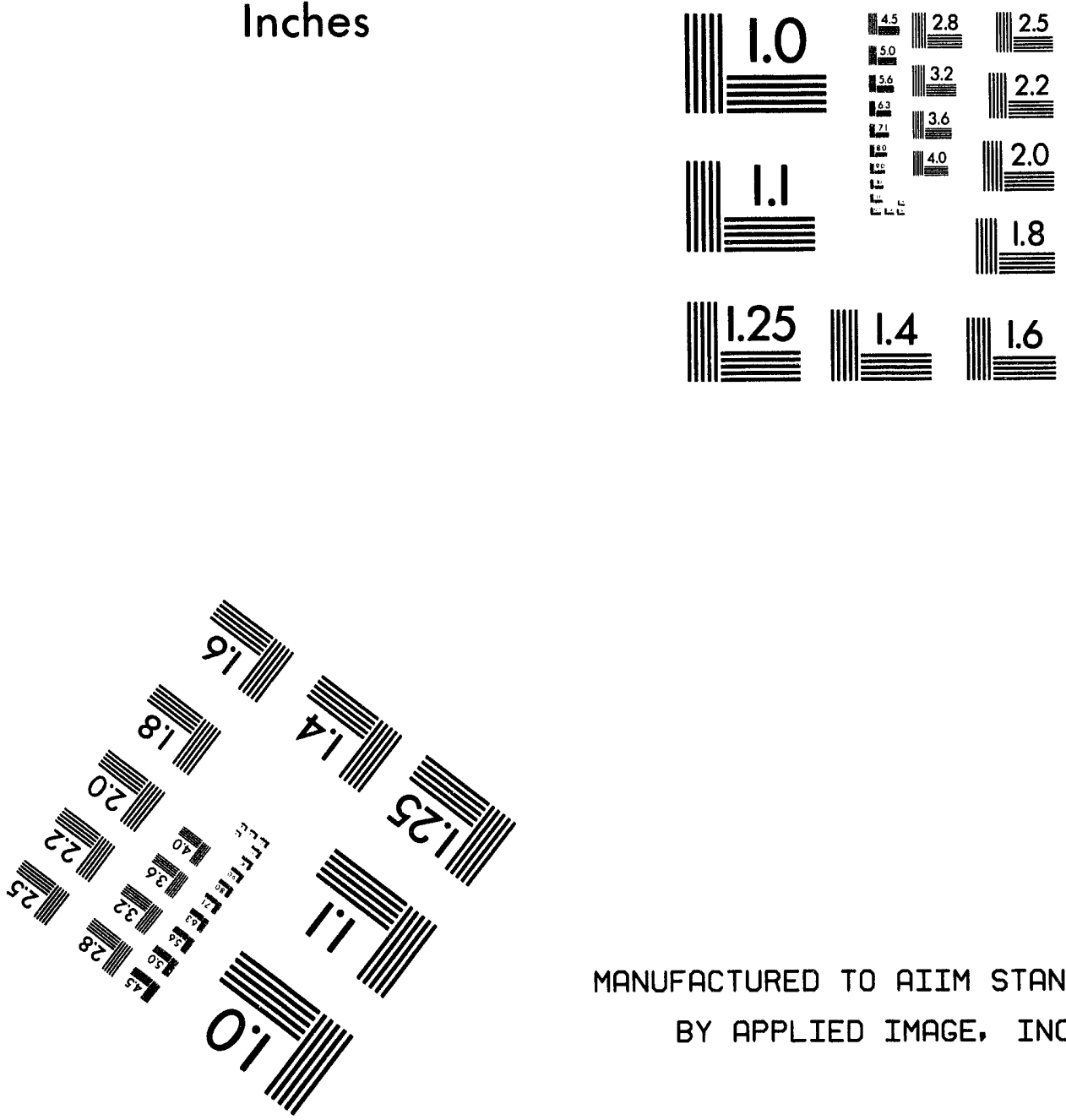

MANUFACTURED TO AIIM STANDARDS BY APPLIED IMAGE, INC.

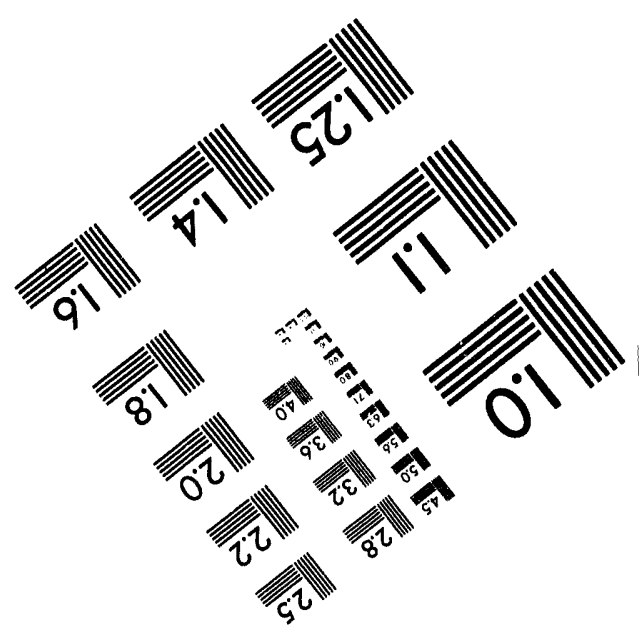



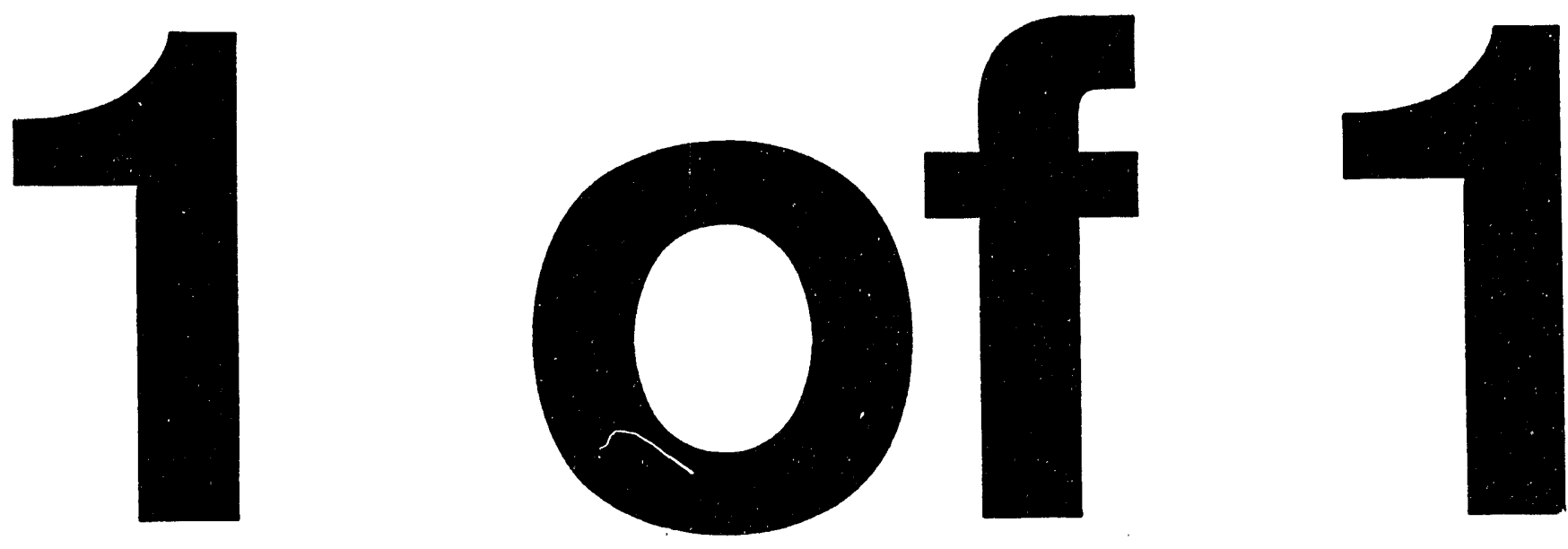


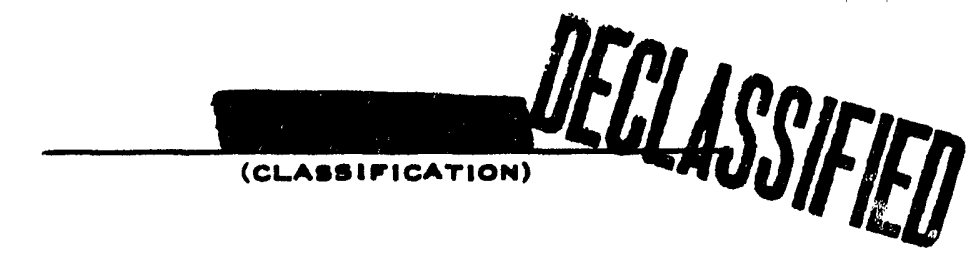

\section{GENERAL OLECTRIC}

HANFOND ATOMIC PRODUCTE. OPERATION - RICHLAMD, WASHINOTON

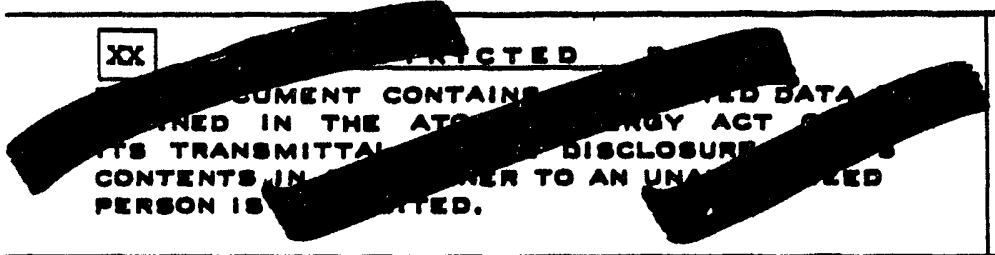

TITLE

CRE-4-68, 69, 70: PROPOSAL FOR

VARIABLS BRAKA THICKUTHSS IRRADIATION

genice AND COPY NO.

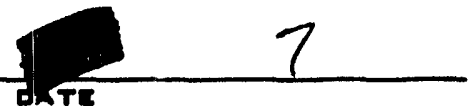

June 27,1961

OTHER OFFICIAL CLAGSIFIED INFORMATION

THIS MATERIAL CONTAINE INFONMATION AFFECTINO THE NATIONAL DEFENSE OF THE UNITED ETATES WITHIN THE MEANING OF THE ESPIONACE LAWS, TITLE 10, U.S.C., EECS. TOS AND MeA, THE TRANEMISEION ON REVELATION OF WHICH IN ANY MANMER TO AN UNAUTHORIzED PERSON IO PROHIDITED DY LAW.

\section{AUTHON}

J. C. Trerbers

I. E. Kusler
COAPY RECEIVED 300 AREA

$$
\text { JUL } 311961
$$

\section{ReIUNIV 10}

TECHWICAL INFORMATION FILES

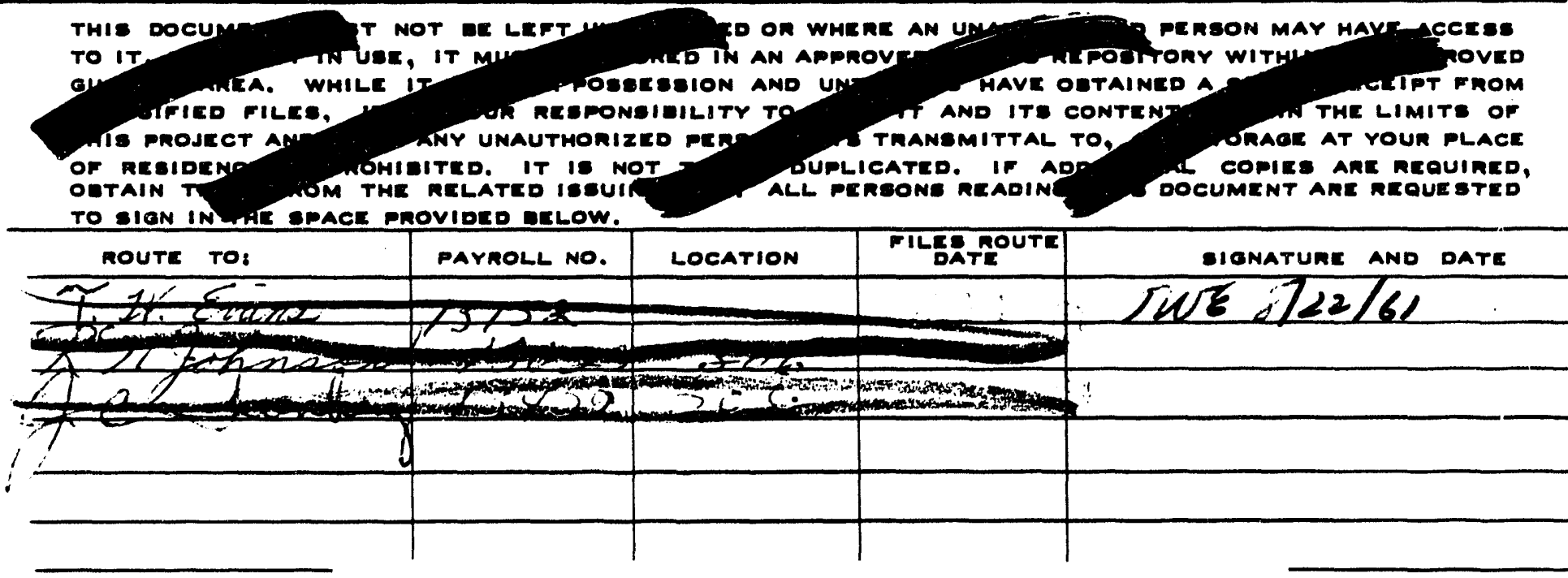

DISCLAIMER

This report was prepared as an account of work sponsored by an agency of the United States Government. Neither the United States Government nor any agency thereof, nor any of their employees, makes any warranty, express or implied, or assumes any legal liability or responsibility for the accuracy, completeness, or usefulness of any information, apparatus, product, or process disclosed, or represents that its use would not infringe privately owned rights. Reference herein to any specific commercial product, process, or service by trade name, trademark, manufacturer, or otherwise does not necessarily constitute or imply its endorsement, recommendation, or favoring by the United States Government or any agency thereof. The views and opinions of authors expressed herein do not necessarily state or reflect those of the United States Government or any agency thereof.

\begin{tabular}{l|l|l|l|l|}
\hline & & & & \\
\hline & & & & \\
\hline 54-3000-340 (3-57) atc.er niemlano. wasm. & & & \\
\hline & & &
\end{tabular}


Th1s document consists of 16 peges, No. 7 of

Craimonion Concalled and Chanped To

22 copies.

DECLSSFIFIED

- Aunoty of RMrlten

GR-4-68, 69, 70: PROPOSAL FOR

$3-1-24$ CGNREZ

o Es savele 3-7-99

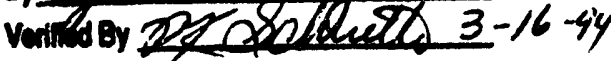

VARIABIS BRAZS THICKIESS IRRADIATION

by

J. C. Trerberg

Tuels Fabrication Development

Reactor and Fuels Research and Development

BAITORD IABORATORTES
L. E. Kusler

Coextruded Product Englneerling FUEIS PREPARATION DFPARIMLNT

June 27, 1961

\section{DISTRIBUITIN}

1-2. E. F. Thurston

3. T. W. Ambrose

4. S. - H. Bush

5. J. J. Cadwell

6. A. C. Callen

7. T. W. Bvans

8. S. M. Gill

9. E. N. Heck

10. R. S. Kemper

11. W. K. Kratzer

12. I. E. Kusler
13. G. A. Last

14. C. G. Iewis

15. J. E. Minor

16. R. E. Olson

17. J. C. Tverberg

18. P. M. Midkiff/J. H. Sako - AEC-HOO

19. R. R. O'Connor - PPC/NRTS

20. 300 Area Files

21. Records Center

22. Extra

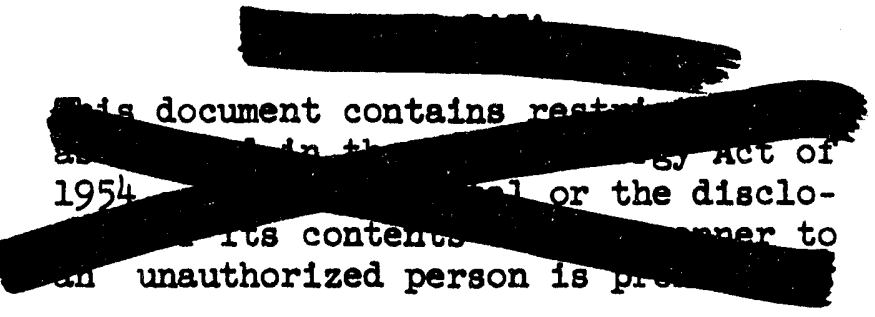

This Document Classified By:

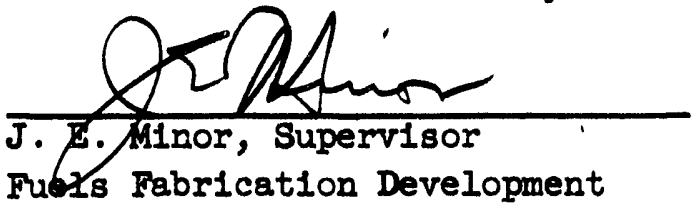




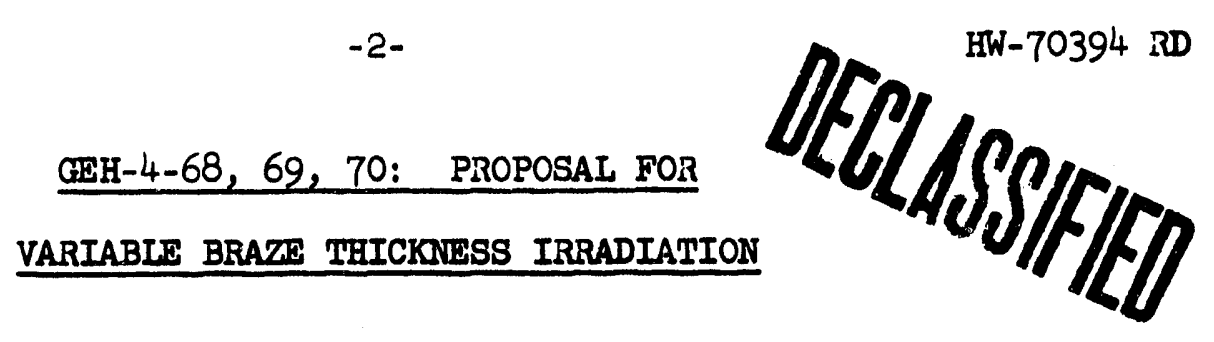

I. INTRODUCTION

Current NPR fuel production plans call for a thick layer $(0.030$ inch or greater) of $5 \% \mathrm{Be}+95 \% \mathrm{Zry}-2$ braze alloy in the closure region. This requirement was imposed to eliminate many of the production welding problems brought about by the presence of the low melting braze alloy between two surfaces of Zircaloy. AIl GE-4 irradiations in the past have involved very thin braze lines ( 0.015 inch or less). As a part of the fuel evaluation program it is essential to run a comparative irradiation to determine what effect the braze line thickness has on the stability of the fuel closure. For this purpose three fuel elements were prepared, two with a braze thickness of 0.030 inch and one with a braze thickness of 0.015 inch. To provide a more severe thermal stress, the I\&s geometry was used. Five MTR cycles should be sufficient to test thls fuel concept.

\section{DESCRIPTION OF FUEL ELPMENTS}

Th1s irradiation test consists of three fuel elements. The fuel material is normal metallic unalloyed uranium, Zircaloy-2 clad, of the tubular geometry and the I\&W size. The fuel was coextruded at Hanford by the Fuels Preparation Department. Each element is 7.50 inches in length with contoured end caps. The Zircaloy-2 end caps were brazed to the jacket and uranium core with the 5\% Be + 95\% $\mathrm{Zry}-2$ braze alloy, then TIG welded to further insure closure integrity. Braze line thickness was malntained by controlling the diameters of the end caps. The elements are 1.450 inches OD and 0.436 inch ID. For hydraulic purposes a 0.326 inch diameter flow restrictor has been fitted into the central flow channel of both elements. A one inch high perforated aluminum spacer supports the two elements. This entire fuel assembly is contained in a standard $\mathrm{CEH}-4$ basket.

\section{SUMMARY OF TEST CONDITIONS}

Maximum Fuel Core Temperature

Maximum Uranium Surface Temperature

Maximum Jacket Temperature

Normal Uranium Welght

Total Uranilum Welght (Three Elements)

Welght U235 (Three Elements)

Maximum Power Generation

Maximum Heat Flux (Outer Surface)

Number of Fuel Elements

Number of MTR Cycles

Burnup Rate (Per Day)

Water Flow Rate

Water Velocity

Film Coefficient

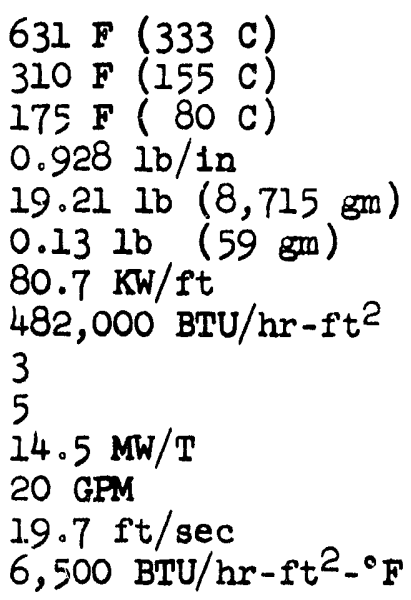


External Fuel Dlameter

Internal Fuel Diameter

Internal Basket Diameter at Tuel

Flow Restrictor Diameter

\title{
-3.
}

\author{
1.450 inches \\ 0.436 inch \\ 1.560 inches \\ 0.326 inch
}

\section{FABRICATION}

The fuel tubes were coextruded by the floating mandrel process at $1170 \mathrm{~F}$ and an extrusion ratio of $18: 1$. Extruded dimensions were $1.459 \pm 0.007$ inches OD and $0.429 \pm 0.005$ inch ID, with a nominal 0.025 inch thick zircaloy-2 cladding.

Transverse and longltudinal sections were examined for dimensions, uranium quality and bond quality. Extrusion copper was removed by nitric acid pickling. The extrusions were cut into 7.65 inch lengths and the uranium removed to a depth of 0.36 inch on each end by imersion in a solution of sulfuric acid, nitric acid, copper sulfate and water.

The cladding was then vapor blasted to remove surface contamination, then bright etched in the $\mathrm{HF}-\mathrm{ENO}_{3}$ etch solution. A 0.315 inch thick Zircaloy cap was placed on the uranium and the Zircaloy walls were crimped to hold the cap tightly against the uranium. A braze alloy ring was placed on the cap and the assembly positioned in a vacuum brazing chamber and evacuated to $10-3 \mathrm{~mm}$ of $\mathrm{Hg}$. The closure region was heated to $1035 \mathrm{C}$, and as soon as the braze alloy melted the vacuum valves were closed and the system pressurlzed with argon gas to force the braze alloy to flow under the cap.

After brazing the elements were beta heat treated in chlorlde salt at $730 \mathrm{C}$ and quenched into nitrate salt. The elements were then machined to the proper end contour, vapor blasted to remove the heat treating scale and bright etched. The elements were then TIG welded, inspected and autoclaved for 72 hours in $400 \mathrm{C}$ $(750 \mathrm{~F}) 1500 \mathrm{ps} 1$ steam to Insure adequate corrosion resistant welds and good quality Zircaloy-2 surfaces. Final inspection included a visual check for marred surfaces, pre-1rradiation measurements, radiographs of the closure, an ultrasonic bond check and a clad thickness Eddy Current Test.

\section{FLUX WIRES}

One flux wire shall be attached to the basket and remain attached throughout the irradiation. Two flux wires, one toward the reactor core and one away from the core, shall be placed in the flux wire slots: and shall be replaced at the startup of each cylce. The flux valves shall be forwarded to the experimenter as soon as they become avallable. It is imperative that this be done so that a complete record is obtained of the flux for each cycle and for the entire irradiation.

VI. REQUIRFH FUEL EXAMINATION

Perlscope photographs shall be taken as soon as possible following final discharge of the irradiated elements in the canal. A complete radiometallurgical examination will be dore at HAPO. 
VII. SFECIMEN INSERTION AND REMOVAL

The fuel elements and an MTR basket will be shipped to the MTR/FTR site after approval of this Irradiation proposal. The element: shall be placed in the basket with the numbered end up, and with GeH-4-68 as the upper element (thin braze), GEH-4-69 as the center element (wide braze) and GHH-4-70 as the bottom element (wide braze). The pointed end shall be oriented in the upward direction. Inlet and outlet thermocouples will be provided.

VIII. HAZARDS

There are no unusual hazards assoclated with this irradiation because of the very low uranlum temperature. The cladding, braze alloy and welds have been subjected to autoclave conditions much more severe than actual reactor operating conditions.

IX. APPHIDICAS

Detalls of all pertinent information are appended in the following order:

APPWIDIX I: Thermal and Hydraulic Calculations

APPFNDIX II: F1gures 


\section{APFEIDIX I - THEFEAL AND BYDRAUITC CAICULATIONS}

A. For calculation purposes, the spectflc power generation was taken from data obtained from the nuclearly similar test GH-4-57, 58. This test produced a measured average power generation of $74 \mathrm{~kW} / \mathrm{ft}$ or $7.25 \mathrm{~kW} / \mathrm{lb}$ of natural uranium. As these elements, GSH-4-68,69,70, contain $0.928 \mathrm{lb}$ of natural uranlum per lnch, a power generation of $80.7 \mathrm{~kW} / \mathrm{ft}$ may be expected. The maximum heat flux will be approximately $482,000 \mathrm{BTU} / \mathrm{hr}-\mathrm{ft} \mathrm{f}^{2}$ on the outer surface.

B. Sample Calculations

Basic Conditions:

Urantum Core

\section{Length \\ Outer Diameter \\ Inner Diameter}

Fuel w1th Cladding
6.90 Inches

1.400 inches

0.486 Inch
Leagth

Outer Diameter

Inner Dlameter

- Cap Thickness

Clad Thlckness (Both Inner and Outer)
7.50 inches

1.450 inches

0.436 inch

0.280 inch

0.025 inch

1. Flow Arees

Basket $=\pi / 4(1.560)^{2}=$

Outer Annulus $=\pi / 4 \quad\left[(1.560)^{2}-(1.450)^{2}\right]=$

$1.9111 \mathrm{n}^{2}=0.0133 \mathrm{ft}^{2}$

Inner Annulus $=\pi / 4$

$0.260 \mathrm{in}^{2}=0.00180 \mathrm{ft}^{2}$

$0.066 \mathrm{in}^{2}=0.000458 \mathrm{ft}^{2}$

2. Pertpherles

Basket $=\pi(1.560)=$

Fuel OD $=\pi(1.450)=$

Fuel ID $=\pi(0.436)=$

Flow Restrictor $=\Pi(0.326)=$
4.900 in $=0.408 \mathrm{ft}$

$4.555 \mathrm{in}=0.3796 \mathrm{ft}$

$1.370 \mathrm{in}=0.114 \mathrm{ft}$

$1.024 \mathrm{fn}=0.0853 \mathrm{ft}$ 


\section{Power Generation}

The specif1c power generation in chil-4-57, 58 was measured at $7.25 \mathrm{~kW} / \mathrm{lb}$ of natural uranium.

$Q=\frac{0.928 \mathrm{lb} \text { natural U }}{\text { In }} \times \frac{7.25 \mathrm{KW}}{1 \mathrm{~b} \text { natural U }} \times \frac{12 \mathrm{In}}{\mathrm{ft}}=80.7 \mathrm{~kW} / \mathrm{ft}$

4. Equivalent Diameters

a. Outer Annulus

$D e=\frac{4 A}{S}=\frac{4(0.260)}{4.900+4.555}=0.1099$ Inch

b. Inner Annulus

$$
D e=\frac{4(0.066)}{1.370+1.024}=0.1102 \text { Inch }
$$

5. Flow Split

$$
\begin{aligned}
& \text { Inlet water flow }=208 \mathrm{pm} \\
& v_{1}=\left(\frac{\left(\overline{D e}_{1}\right.}{\left(\overline{D e}_{2}\right)}\right)^{-1.8} \mathrm{v}_{2} \\
& \text { Let } v_{1}=1 \\
& \text { Then } v_{2}=\left(\frac{\left(e_{1}\right.}{D_{2}}\right)^{1.8}=\left(\frac{0.1099}{(0.1102}\right)^{1.8}=(0.997)^{1.8}=0.995
\end{aligned}
$$

For all practical purposes, consider the velocitles equal in both the inner and outer annuli.

The flow split will then be:

$$
\begin{aligned}
Q_{T}=Q_{0}+Q_{1} & =V_{0} A_{0}+V_{1} A_{1} \\
\text { But } V_{0} & =V_{1} \\
\text { QT } & =V_{0}\left(A_{0}+A_{1}\right)
\end{aligned}
$$




$$
\begin{aligned}
& \frac{20 \times 0.1337}{60}=v_{0}(0.00180+0.000458) \\
& v_{0}=19.7 \mathrm{ft} / \mathrm{sec} \\
& Q_{0}=(19.7)(0.00180)(448.8)=15.9 \mathrm{gal} / \mathrm{m} 1 \mathrm{n} \\
& Q_{1}=(19.7)(0.000458)(448.8)=4.1 \mathrm{gal} / \mathrm{min}
\end{aligned}
$$

\section{F1lim Coefficients}

The Modifled Colburn Equation was used to compute the film coefficients.

$$
\mathrm{b}=0.023 \frac{\mathrm{K}_{f}}{\mathrm{D}_{e}}\left[\frac{\mathrm{D}_{\mathrm{e}} \mathrm{G}}{\mu}\right]_{f}^{0.8}\left[\frac{\mathrm{C}_{\mathrm{p}} \mu}{\mathrm{K}}\right]_{f}^{0.3}
$$

where

$h=f 11 m$ coefficient BTU/hr-ft ${ }^{2}{ }^{\circ} \mathrm{F}$

$D_{e}=$ equivalent diameter - ft

$G=$ mass veloc1ty $1 b / h r-f t^{2}$

$\mu=$ dynamic $v 1 s \cos 1 \mathrm{ty} I \mathrm{~b} / \mathrm{hr}-\mathrm{ft}$

$C_{p}=$ specific heat $B T U / 1 b-{ }^{\circ} \mathrm{F}$

$K=$ thermal conductivity BTU $/ \mathrm{hr}-\mathrm{ft}-{ }^{\circ} \mathrm{F}$

Outer Annulus

Assume a f1lm temperature of $170 \mathrm{~F}$.

$D_{e}=0.00916 \mathrm{ft}$

$\mu=0.90 \mathrm{Ib} / \mathrm{hr}-\mathrm{ft}$

$\mathrm{C}_{\mathrm{p}}=1.00 \mathrm{BTU} / \mathrm{Ib}-{ }^{\circ} \mathrm{F}$

$K=0.388 \mathrm{BTU} / \mathrm{hr}-\mathrm{ft}-{ }^{\circ} \mathrm{F}$

$G=\frac{15.9 \mathrm{Gal} / \mathrm{Mln} \times 8.122 \mathrm{lb} / \mathrm{gal} \times 60 \mathrm{mln} / \mathrm{hr}}{0.00180 \mathrm{ft}^{2}}=4,300,000 \mathrm{lb} / \mathrm{hr}^{2} \mathrm{ft}^{2}$ 


$$
\begin{aligned}
\mathbf{b} & =\frac{0.023 \times 0.388}{0.00916}\left[\frac{0.00916 \times 4.3 \times 10^{60}}{0.9}\right]^{0.8}\left[\frac{1 \times 0.9}{0.388}\right]^{0.3} \\
& =0.974\left[4.37 \times 10^{40.8}\left[2.33^{0.3}\right.\right. \\
& =0.974[5.16 \times 103] \\
& =6,450 \mathrm{BTU} / \mathrm{hr}-\mathrm{ft}^{2}-{ }^{\circ} \mathrm{F}
\end{aligned}
$$

\section{Inner Annulus}

$D_{e}=0.00916 \mathrm{ft}$

$\mu=0.90 \mathrm{Lb} / \mathrm{hr}-\mathrm{ft}$

$C_{p}=1.0 \mathrm{BTU} / 1 \mathrm{~b}-{ }^{\circ} \mathrm{F}$

$K=0.388 \mathrm{BTU} / \mathrm{hr}-\mathrm{ft}-{ }^{\circ} \mathrm{T}$

$G=\frac{[4.1][8.122][60]}{[0.000458]}=4,360,000 \mathrm{lb} / \mathrm{hr}-\mathrm{ft}^{2}$

$h=\left[\frac{0.023 \times 0.388}{0.00916}\right]\left[\frac{2.16 \times 10^{-3} \times 4.36 \times 10^{6}}{0.90}\right]^{0.8}\left[\frac{1 \times 0.9}{0.388}\right]^{0.3}$

$=(0.974)\left(4.44 \times 10^{4}\right)^{0.8}(2.32)^{0.3}$

$=(0.974)\left(5.22 \times 10^{3}\right) \quad(1.287)$

$=6,500 \mathrm{BTU} / \mathrm{hr}-\mathrm{ft} \mathrm{t}^{2}-{ }^{\circ} \mathrm{F}$

$$
\begin{aligned}
r_{\max } T & =\sqrt{\frac{(.490-(0.059)}{2 \ln 2.88}}=\sqrt{\frac{0.431}{2.116}}=\sqrt{0.2037} \\
& =0.451 \mathrm{inch}
\end{aligned}
$$


Heat Flow

Area to Inner annulus $A_{1}=\prod\left(r_{\max } T^{2}-r_{1}^{2}\right)$

$=\pi(0.2037-0.059)=0.455 \mathrm{in}^{2}$

Area to outer annulus $A_{0}=\pi\left(r_{0}^{2}-r_{\max } T^{2}\right)$

$=\pi(0.4900-0.2037)=0.899 \mathrm{in}^{2}$

Heat flow to outer surface

$$
=\frac{0.899}{0.899+0.455} \times 100=66.4 \%
$$

Heat flow to Inner surface

$$
\frac{0.455}{1.354} \times 100=33.6 \%
$$

\section{Heat Flux}

Outer Annulus

$80.7 \frac{\mathrm{KW}}{\mathrm{ft}} \times 3412 \underset{\mathrm{KWH}-\mathrm{hr}}{\mathrm{BTU}} \times 0.664 \times \frac{1}{0.380 \mathrm{ft}}=482,000 \mathrm{BTU} / \mathrm{hr}-\mathrm{ft}^{2}$

Inner Annulus

$80.7 \frac{\mathrm{KW}}{\mathrm{ft}} \times 3412 \frac{\mathrm{BTU}}{\mathrm{KW}-\mathrm{hr}} \times 0.336 \times \frac{1}{0.114 \mathrm{ft}}=81,000 \mathrm{BTU} / \mathrm{hr}-\mathrm{ft}^{2}$

9. F1Im Temperature Drop

Outer Annulus

$$
\frac{482,000}{6,450}=74.7 \mathrm{~F}(41.5 \mathrm{C})
$$

Inner Annulus

$$
\frac{81,000}{6,500}=12.5 \mathrm{~F}(6.9 \mathrm{C})
$$


10. Cladding Temperature Drop

$$
\Delta t_{0}=\frac{543.5 \mathrm{Q}}{\mathrm{K}} \text { in } \frac{r_{\mathrm{a}}}{\mathrm{r}_{1}} \quad \begin{aligned}
& \text { (Tuel Element Design Handbook, } \\
& \text { Page A-100-6) }
\end{aligned}
$$

\section{where}

$Q=$ specific power $\mathrm{kW} / \mathrm{ft}$

$r_{2}=$ outer radius

$r_{1}=$ Inner radius

$K=$ thermal conductivity-Z1rcaloy @ $212 \mathrm{~F}=8.12 \mathrm{BTU} / \mathrm{hr}-\mathrm{ft}-{ }^{\circ} \mathrm{F}$

\section{Outer Annulus}

$$
\begin{aligned}
Q & =80.7 \times .664=53.6 \mathrm{~kW} / \mathrm{ft} \\
r_{2} & =0.725 \mathrm{inch} \\
r_{1} & =0.700 \mathrm{inch} \\
\Delta t_{0} & =\frac{(543.5)(53.6)}{8.12} \text { in } \frac{0.725}{0.700}=(66.9)(53.6)(0.036) \\
& =129 \mathrm{~F}(71.7 \mathrm{C})
\end{aligned}
$$

\section{Inner Annulus}

$$
\begin{aligned}
Q & =80.7 \times 33.6=27.1 \mathrm{~kW} / \mathrm{ft} \\
r_{2} & =0.243 \\
r_{1} & =0.218 \\
\Delta t_{0} & =(66.9)(27.1) \text { in } \frac{.243}{.218}=(1813)(0.109) \\
& =197.6 \mathrm{~F}(109.8 \mathrm{c})
\end{aligned}
$$

11. Coext:ruded Bond Temperature Drop

$\Delta t$ assumed to be zero 
12. Uranium Temperature Drop

The temperature drop 18 calculated from the adlabat1c radius to the outside of the tubular core. (Reference: ANL-4690, Page 9, Case III)

$$
\begin{aligned}
& \Delta t_{\left(r_{0}-r_{\max } T\right)}=\frac{q}{2 K} \frac{\left(r_{0}^{2}-r_{\max }^{2}\right)}{2}-r_{\max }^{2} \frac{2 n \frac{r_{0}}{r_{\max } T}}{} \\
& \text { where } \\
& q=\frac{Q / f t}{V 01 / f t}=\frac{(80.7)(3412)(4)}{12\left(1.400^{2}-0.486^{2}\right)(\pi)}=16,950 \mathrm{BTU} / \mathrm{hr}-1 \mathrm{n}^{3} \\
& \mathrm{~K}=\text { urantum thermel conductivity }=\frac{1196+\mathrm{t}\left({ }^{\circ} \mathrm{C}\right)}{83.4} \\
& =\frac{1196+200}{83.4}=16.8 \mathrm{BTU} / \mathrm{hr}-{ }^{\bullet} \mathrm{P}-\mathrm{ft}=1.4 \mathrm{BTU} / \mathrm{hr}-{ }^{\bullet} \mathrm{F}-\text { in } \\
& \Delta t=\frac{16,950}{(2)(1.4)}\left[\frac{\left(0.700^{2}-0.451^{2}\right)}{2}-0.451^{2} \text { in } \frac{0.700}{0.451}\right] \\
& =6,054(0.143-0.090) \\
& =320.8 \mathrm{~F}(178.2 \mathrm{C})
\end{aligned}
$$

\begin{tabular}{|c|c|c|}
\hline & Outer Annulus & Inner Annulus \\
\hline $\begin{array}{l}\text { Inlet Water } \\
\text { Clad Surface } \\
\text { Urantum Surface } \\
\text { Urantum Core (Max) }\end{array}$ & 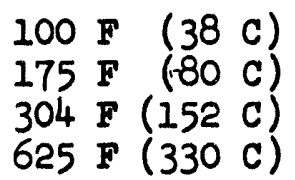 & 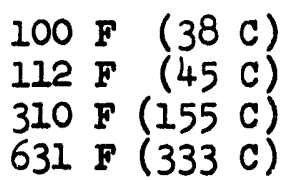 \\
\hline
\end{tabular}

13. Temperature Sumary

14. Pressure Balance

Pressure drop estimates were determined by the "velocity head" method, with reference made to the Reactor Handbook, Engineering Volume.

a. Annular Velocities:

$$
\begin{aligned}
& v_{0}=19.7 \mathrm{ft} / \mathrm{sec} \\
& v_{1}=19.7 \mathrm{ft} / \mathrm{sec}
\end{aligned}
$$


b. Velocity Head $=\frac{v^{2}}{2 g}$

Outer Annulus:

$$
\frac{(19.7)^{2}}{2(32.2)} \times \frac{62}{744}=2.595 \mathrm{po1}
$$

Inner Annulus:

$=2.595 \mathrm{ps} 1$

c. Reynolds Number

$$
\begin{aligned}
& N_{R}=\frac{D e v \rho}{\mu} \quad N_{R}=\text { Reynolds Number } \\
& \text { De = Equivalent Diameter ( } f t \text { ) } \\
& v=\operatorname{Veloc1ty}(\mathrm{ft} / \mathrm{sec}) \\
& \mu=\text { V1scosity of Water at } 100 \mathrm{~F} \\
& =4.58 \times 10^{-4} 1 \mathrm{~b} / \mathrm{sec}-\mathrm{ft} \\
& \rho \text { = Density of Water at } 100 \mathrm{~F} \\
& =62 \mathrm{lb} / \mathrm{ft}^{3}
\end{aligned}
$$

Outer Annulus:

$$
\begin{array}{cl}
N_{R} & =\frac{(0.1099)(19.7)(62.0)}{(12)\left(4.58 \times 10^{-4}\right)} \\
& =2.44 \times 10^{4} \\
\text { Inner Annulus: } & N_{R}=2.46 \times 10^{4}
\end{array}
$$

d. Friction Factor

Read from Reector Handbook, Engineering Volume, Flgure 1.5 .2

Outer Annulus:

$$
f_{0} \quad=0.025
$$

Inner Annulus:

$$
f_{1}=0.025
$$


e. Priction Loss

$$
\Delta P=\frac{(f)(L)\left(V_{h}\right)}{D E} \quad \begin{aligned}
f & =\text { friction factor } \\
L & =\text { fuel column length (Inches) } \\
D & =\text { equivalent diameter } \\
\Delta P & =\text { pressure drop (psi) }
\end{aligned}
$$

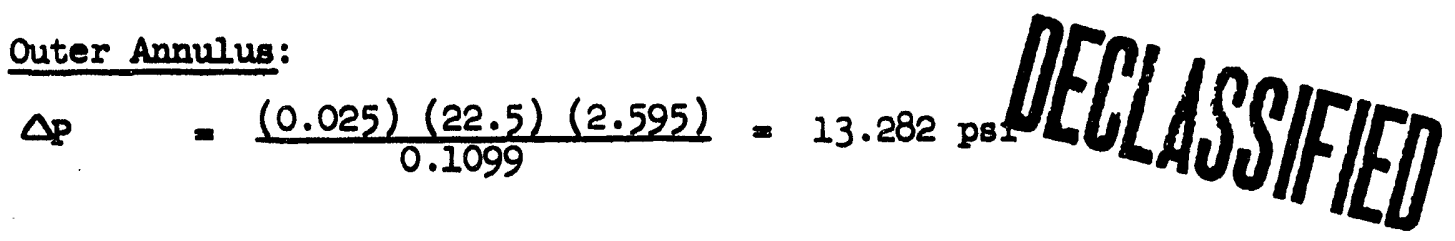

Inner Annulus:

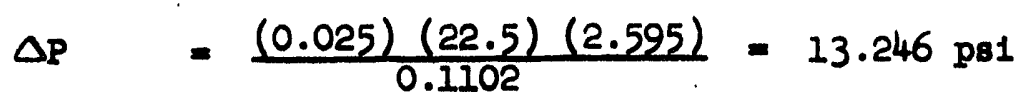

f. Contraction and Expansion LOBB

$\Delta P=K\left(V_{h}\right)$

Coefflclent "K" read from Reactor Handbook,

Bnglneering Volume, F1gures 1.5 .6 and 1.5.7

\section{Outer Annulus:}

$A_{0}=$ Annulus Area $=0.260 \mathrm{in}^{2}$
$A_{b}=$ Basket Area $=1.911 \mathrm{in}^{2}$

$$
\frac{A_{0}}{A_{b}}=\frac{0.260}{1.911}=0.136
$$

$\mathrm{Kc}=0.39$

$$
\begin{aligned}
\Delta P & =(0.39)(2.595) \\
& =1.012 \mathrm{ps1} \text { contraction 1088 } \\
& \mathrm{K}=0.74 \\
\Delta P \quad & =(0.74)(2.595) \\
& =1.920 \mathrm{ps1} \text { expansion 1088 }
\end{aligned}
$$




\section{Inner Annulus:}

$$
\begin{aligned}
& A_{1}=\text { Inner Annulus }=0.066 \mathrm{in}^{2} \\
& \text { Ab }=\text { Basket Area }=1.911 \mathrm{in}^{2} \\
& \frac{A_{1}}{A_{b}}=\frac{0.066}{1.911}=0.035 \\
& \mathrm{Kc}=0.40 \\
& \Delta P \quad=(0.40)(2.595) \\
& =1.038 \mathrm{ps1} \text { contract1on.1088 } \\
& \text { Ke } \quad=0.95 \\
& \Delta P \quad=(0.95)(2.595) \\
& =2.465 \text { psi expansion } 1088
\end{aligned}
$$

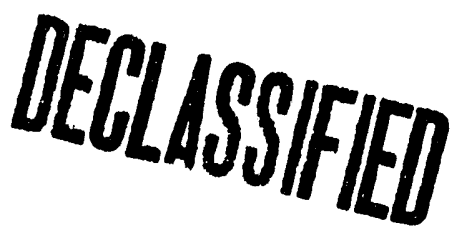

Total Pressure Drop

Ios8

Friction

Contraction

Expansion
Outer Annulus

13.282

1.012

1.920

Total - $16.214 \mathrm{psi}$ 
TIG Weld (TYP Both Ends)

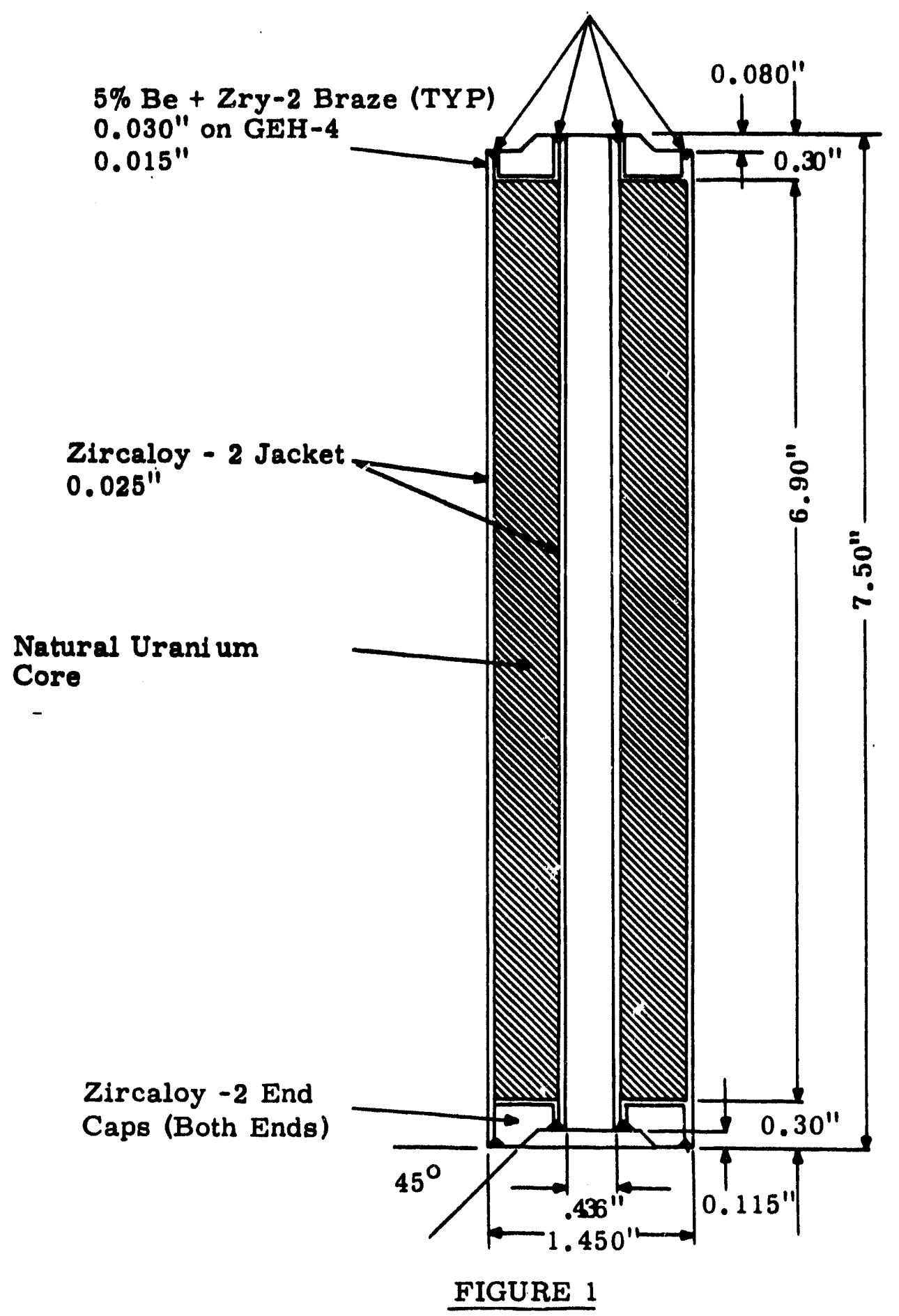

Cross Sectional View of Fuel Elements for MTR Irradiation GEH-4-68, 69, 70 


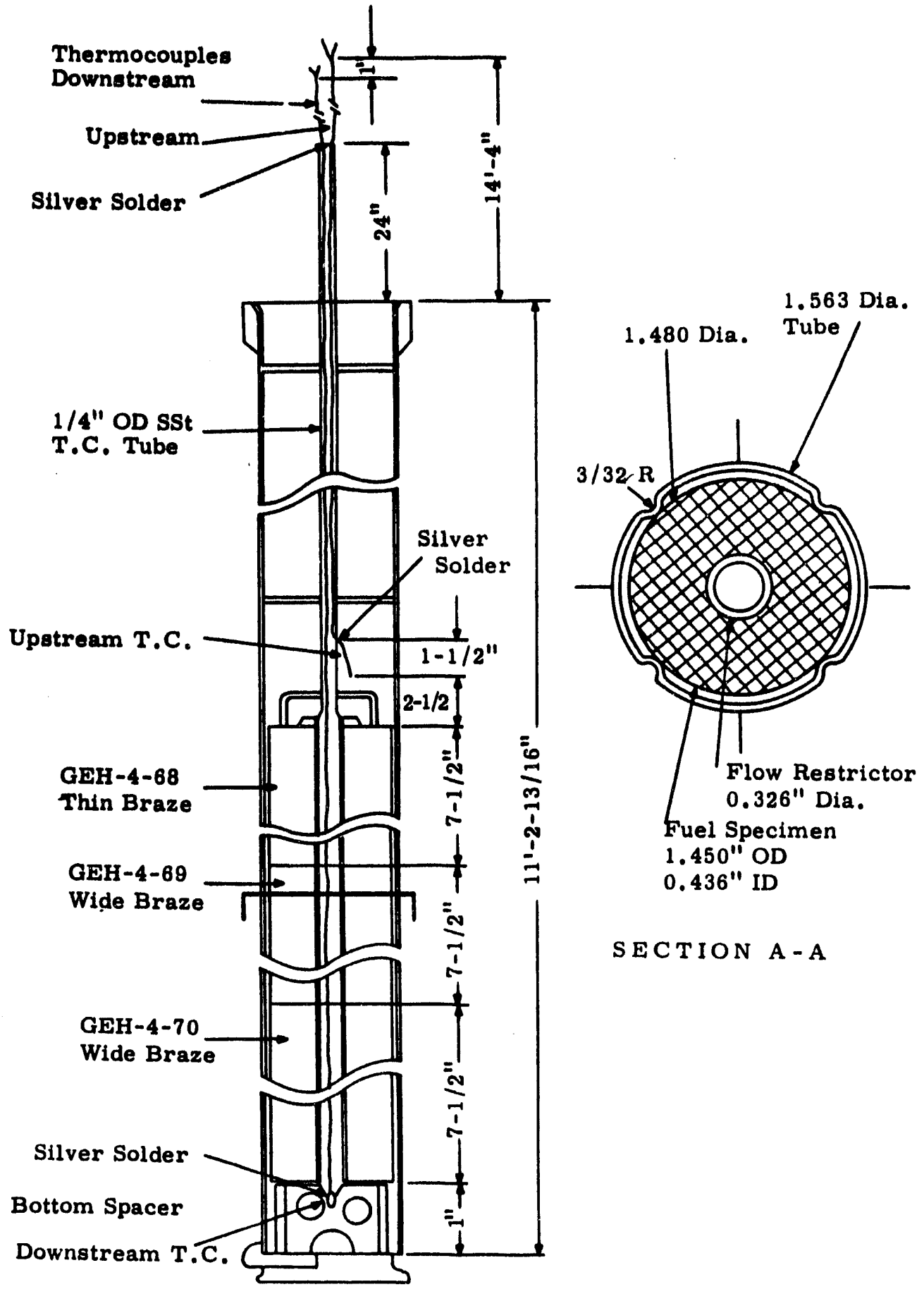

FIGURE 2

Basket Arrangement for GEH-4-68, 69, \& 70 

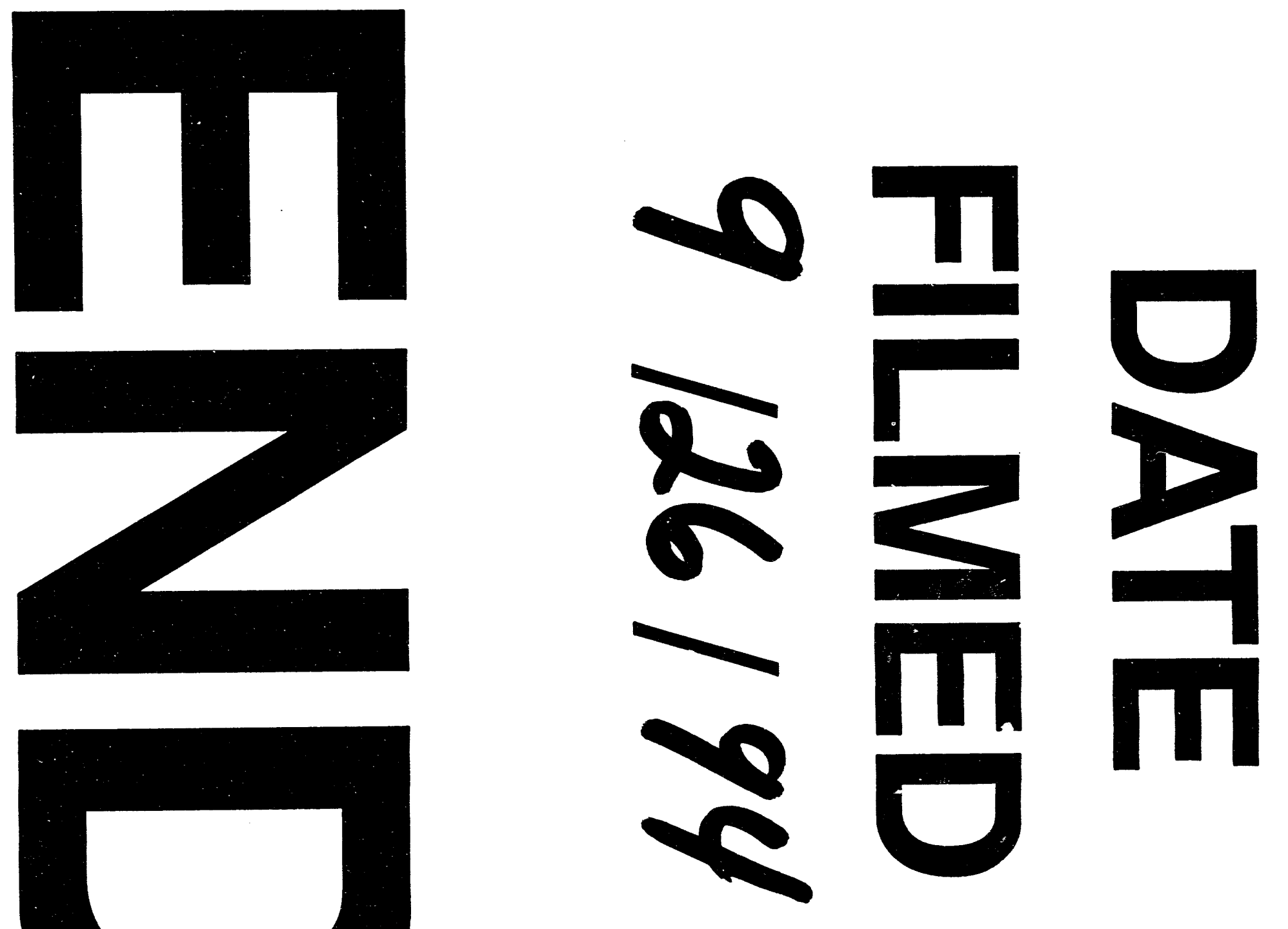


$$
-
$$

